\title{
History, Challenge and Opportunities of Beles (Oppuntia ficus indica L.) in Tigray, North Ethiopia
}

\author{
Shushay Welderufael \\ Department of Plant Science, Adigrat University, Adigrat, Ethiopia, PO. Box, 50
}

\begin{abstract}
Oppuntia ficus indica which is known as 'Beles' in Tigray northern Ethiopia, is adapted to arid and semiarid areas and is used for several purposes like sources of food, fuel, feed, sources of income soil conservation for the people of the area. However, this crucial fruit crop is given little attention in its research and improvements. Let alone its improving through breeding techniques takes place for this crop, the number of cactus verities grown is unknown, agronomic techniques are very traditional. On top of this, there could be a probability that this plant to be a weed in the future unless proper management is practiced. Other than the improper cultivation and interventions, cactus has multiple newly introduced and old biological pests. Among the many biological pests, Cochineal is newly introduced biological pest and explosively expanding from the southern part of Tigray to the remaining part of the region.
\end{abstract}

Keywords: Beles, improvement, uses, challenges, opportunities

\section{Introduction}

Tigray Region is found in northern Ethiopia, with an estimated population of 4.3 million of which $80.5 \%$ live in rural areas. Agriculture is the mainstay of the people, mostly at subsistence level. The land holding per household is small, the soil is degraded and less fertile and rainfall is very erratic. As a result production and productivity is very low and average household production provides food for only 4.5 months of the year. Poverty levels in Tigray Region are high compared to other parts of the country. The interim report on Poverty Analysis Study (2010-11) estimated that $29.6 \%$ of people in Ethiopia are poor (poverty head count index) and $33.6 \%$ of people are food poor (food poverty head count index. In terms of regional distribution, the study revealed that the poverty head count index is the highest in Afar Region $(36.1 \%$ ) followed by Somali Region (32.8\%) and Tigray Region (31.8\%), In terms of food poverty, the highest rates were observed in Amhara Region (42.5\%) followed by Tigray Region (37.1\%) (Population and Housing Census, 2007). Inadequate year round supply and low quality of feed and food resources and continuous degradation of range vegetation are major problems in arid and semi-arid regions like Tigray, north Ethiopia. In addition, irregular availability of roughages and frequent increasing price of concentrate feeds are frightening the productivity and sustainability of livestock production systems. Using of multi-purpose plants is important option in such areas. However, plants that can grow under drought conditions and on low-quality soils are restricted to only few species. Cactus is one of the drought tolerant species and has a number of applications. It is used as a source of food, forage, soil conservation purpose. The multi-purpose uses of cactus empower the rural population to better face the challenges of living in low-rainfall areas.

\section{History of cactus pear in Tigray, North Ethiopia}

Cactus is originated from central and southern Mexico (Griffith 2004). There are different reports with the introduction of cactus pear to Tigray. According to some legends cactus pear locally known as "beles" was introduced between 1848 and 1870 by Catholic Missionaries to eastern zone of Tigray by a priest called "Abune-Yakob" who visited Erob, northern part of Tigray, introduced cactus with the realization of un suitability of the area for cropping and other agricultural activities due to recurrent drought, erratic rainfall, rocky and mountainous topography. As a result the priest brought three spineless cladodes from Mexico, its country of origin (Griffith, 2004) and planted one cladode in Alitena (Erob), the second cladode planted in Golea (Gantaafeshum) and the third cladode planted in Lehe (Eritrea). Then after, the plant was distributed throughout the region and beyond. This is support by Kibra (1992) and Neumann (1997) who reported that missionaries were the ones that introduced cactus to Northern Ethiopia around 1847/8. However, Habtu (2005) reported that Muslim pilgrimages to Mecca (Saudi Arabia) introduced cactus pear to the lowlands of the southern Tigray in 1920.

\section{Importance of Cactus Pear in Tigray}

Over the last few decades interest in cactus pear as food and feed has increased due to its drought resistance, high biomass yield, high palatability and tolerance to salinity (Barbera 1995; Ben Salem et al., 1996). Stintzing and Carle (2005) described cactus pear as a miracle plant, dromedary of the vegetation world, and the bank of life as it can contribute to livelihoods of rural populations in dry areas. Therefore, cultivation of the plant may assume greater agricultural importance in dry areas since a larger part of the land is destined to become arid or semi-arid due to climate change (Snyman 2006). It uses food, livestock feed, cash income, environmental protection, fence, fire wood, cochineal production and bee forage (Gebremeskel et al., 2013). As king Philip III of Spain states one of the most valuable fruits grown in our western Indies is the cactus pear, produce of equal value to gold and silver (Velásquez, 1998), the crop is also mentioned in Tigray in traditional songs (Brutsch, 1997) as well as repeated in local sayings, such as: "A farmer without Beles is like a stream without water". It grows profusely 


\section{International Journal of Science and Research (IJSR) \\ ISSN (Online): 2319-7064}

Index Copernicus Value (2013): 6.14 | Impact Factor (2015): 6.391

in Tigray and has adapted perfectly to the arid zones of the country characterized by droughty conditions, erratic rainfall, and poor soils subject to erosion. It thus contributes in times of drought, serving as a life-saving crop to both humans and animals. Brutsch (1997) and Mitiku et al., (2002) also reported that cactus pear in Tigray used as a source of food, forage, fuel wood, cash income, raw material for various industrial products, as live fences and soil conservation purposes. There are increased interests in the cactus from the recognition of its potential contribution to agricultural diversification, their application to the exploitation of marginal lands and changing environments, and their utility as additional income sources for farmers (Padulosi, 1998). Beles has become the major income and food source for about four months of the year and it is very much part of the culture and livelihood of the people in spite of the limited uses. Today it is fully integrated into the landscape of the highlands. Despite being an alien plant that is able to spread aggressively without the presence of any natural enemies, it is accepted now as an integral part of people's environment and food security. The other importance of cactus pear is its ecological success due to the reason that, Opuntia ficus-indica species have nocturnal stomatal opening, so net $\mathrm{CO} 2$ uptake and water loss occur during the cooler part of the 24-hour cycle. This gas exchange pattern is referred to as Crassulacean Acid Metabolism (CAM) because it was studied extensively in the Crassulaceae, although apparently first recognized in the Cactaceae (Ting, 1985; Nobel, 1988). The gas exchange in cactus pear is referred to as Crassulacean Acid Metabolism (CAM) because it was studied extensively in the Crassulaceae, although apparently first recognized in the Cactaceae (Ting, 1985; Nobel, 1988)

\section{Production of cactus pear in Tigray}

Cactus pear is adapted to many parts of Northern Ethiopia. Farmers maintain cactus backyards but most of the fruit harvest comes from the wildly growing cactus plantation (Tesfay et al., 2011). Although it is an important fruit and forage plant, there is no clear cut information about production and managements of cactus pear in Tigray. This means that the production would be high if appropriate management and production strategies are given to this crucial plant. Currently cactus pear is widely spread throughout the region and is believed to cover more than 379,338 hectares of land, i.e., $7.4 \%$ of the total land of the Tigray region (SAERT 1994; Nefzaoui et al., 2010) and becomes the integral part of the people's economy. Tesfay et al., (2011) also reported that in Tigray region alone, uncultivated cactus covered about 32,000 ha of land.

\section{Challenges of cactus pear in Tigray}

Although, in Ethiopia, particularly the northern part is endowed with wide plantation of cactus pear and the people of the area directly or indirectly depends on its wide range of products like food, feed and soil conservation and traditional medicines, this crucial fruit plant is given little attention in its research and improvements. Lack of improved varieties, production techniques and processing technologies contributes to challenges in exploiting the market to the fullest are challenges of this plant in Tigray (Mondragon, 2005) as cited by Giuseppe (2010). Let alone its improving through breeding techniques takes place for this crop, the number of cactus verities grown is unknown, there is no management practices on this vital but undermined plant. Of course some researchers reported that, in Tigray region of Ethiopia there are 60 farmer identified cultivars (Firew 2007) and 34 cactus cultivars have been characterized by Tigray Agricultural Research Institute (Nefzaoui et al., 2010). It is also reported that the area is rich in genetic diversity of cactus pear and these varieties are being eroded from time to time and new naturally hybridized are being created. Thus, it is important that collecting the available germplasm, characterize and possible agronomic managements to be undertaken in order alleviate the genetic erosions and introgressions and thus to improve this vital plant.

Although cactus pear is an integral plant for the economy of the people and also plays an important role in the environmental values in Tigray, the community is not on the right track in exploiting the potential of the tree. Surprisingly, the contribution that farmers are currently gaining from cactus is with zero cultivation practice. The agronomic techniques (harvesting, transporting and storing) are very traditional (Fessehaye, 2010). On top of this, there could be a probability that this plant could be a weed in the future unless proper management is practiced. Other than the improper cultivation and interventions, cactus has multiple newly introduced and old biological pests. Among the many biological pests, Cocheneal is newly introduced biological pest and explosively expanding from the southern part of Tigray to the remaining part of the region.

Even though majority part of Ethiopia including Tigray could be classified in to arid and semi arid areas which inquire multipurpose and drought resistant plant like cactus, still the plant is limited to specific area. This plant is well known only in southern and eastern part of Tigray. The biennial nature and thorny varieties of currently available cactus are other challenges of cactus production. it can be also raised that the other challenges of cactus pear in are its sensitive nature to freezing temperature (Nobel and Bobich, 2002) and can be affected by different insect pests like Opuntia Borer, Zebra Worm, Spine Borer, Gray Chinch Bug, Red Chinch Bug, White Grub, Wireworms, Opuntia Thrips, Blind June Beetle, Moneilema variolaris, Brown Garden Snail and Cochineal Insect (Badii and Flores 2001). Of these, cochineal cactus moth is deliberately introduced for production of days to the south Tigray and is now thought to be the invasive pest of cactus pear in different parts of Tigray region affecting this crop in short period of time. Because of this, there is fear of dispersion of this insect to the other part of Tigray. This insect is becoming a major challenge of Beles in the area because its control method is beyond the people. The successful management of these pests becomes pertinent so as to improve the quality and increase quantity of cactus pear production in the region. However, in Tigray regional state, there are no research 


\section{International Journal of Science and Research (IJSR) \\ ISSN (Online): 2319-7064}

Index Copernicus Value (2013): 6.14 | Impact Factor (2015): 6.391

reports on the type of insects pest, time of occurrence, duration of the pest occurs, level of severity in which the insects attach the plant etc. Persistence and a long-term commitment are required for prickly pear control. Unmanaged, smaller populations may quickly expand and become more difficult to eradicate if early control measures are not taken. There are different management options of cactus pear which include physical, cultural methods, chemical, biological and manual methods (USDA, 2012).

\section{Conclusion}

Generally, cactus pear (Beles) is important for the livelihood of Tigray people as sources of income, direct consumption and soil and water conservation. However, there are challenges like less attention of researchers and thus an availability of improved varieties of cactus pear and newly introduced pests like cochineal insects. Therefore, it is must to collect and improve the available germplasm of the crop, applying proper agronomic practices and controlling these pests.

\section{References}

[1] Badii M. and Adriana E. Flores, 2008. Prickly Pear Cacti Pests and Their Control in Mexico, Florida Entomologist 84(4).

[2] Barbera, G., 1995. History, economic and agroecological importance. In: Agro- ecology,cultivation and uses of cactus pear. Eds. Barbera, G., Inglese, P. \& Pimienta-Barrios, E. (eds.) FAO Plant production and protection paper 132:1-12.

[3] Ben Salem, H., Nefzaoui, A. and Ben Salem, L., 2002. Nitrogen supplementation improves the nutritive value of Opuntia ficus-indica $F$. inermis based diets and sheep growth. Eds. Nefzaoui, \& Inglese, P. Proceedings of the 4th International Congress on Cactus Pear and Cochineal. Acta Horticulturae 581, 317-321.

[4] Brutsch, M.O., 1997. The Beles or Cactus Pear (Opuntia ficus-indica) in Tigray, Ethiopia. J. PACD 2:130-141 Department of Agronomy, Faculty of Agriculture University of Fort Hare

[5] Fessehaaye, D., 2010. Cactus - based development in Tigray and experience from Mexico. Cactusnet newsletter. Special Issue 12. Pp 22-30.

[6] Firew, T., 2007. Evaluation of alternative feed resources for ruminants under arid zones of the tropics and subtropics: The case of cactus pear (Opuntia ficus indica) in Ethiopia. Ph.D Thesis, Humboldt University of Berlin, Germany.

[7] Gebremeskel, G., Getachew A. and Firew T., 2013. Assessment of the potential of cactus pear (Opuntia ficus indica) as livestock feed in Northern Ethiopia, livestock research for rural development 25(2).

[8] Giuseppe, D. B., 2010. Strengthening Cactus Pear production in Tigray and North Wollo. Cactusnet newsletter. Special Issue 12. pp 17-21

[9] Griffith, M.P., 2004. The origins of an important cactus crop, Opuntia ficus-indica (Cactaceae): New molecular evidence. Amer. J. Bot. 91(11): 19151921.
[10] Habtu, L., 2005. Cactus in southern Tigray: Current status, potential uses, utilization and threat. M.Sc. Thesis, Addis Ababa University.

[11] Kibra, K., 1992. Agro-ecological constraints and the role of cactus pear on household food availability. M.Sc. Thesis, Agricultural University of Norway.

[12] Mitku, H. Tesfay B. and Zimmerman, H.G., 2002. Current and potential use of cactus pear in Tigray, NorthernEthiopia. In: Proceeding of IVth International Congress on Cactus Pear and Cochineal. pp. 75-86. (Nefzaoui, A. and Inglese, P. eds.). Acta Hort. 581, ISHS, Hammamet, Tunisia.

[13] Nefzaoui, A., Inglese P and Belay T., 2010. Improved utilization of cactus pear for food, feed, soil and water conservation and other products in Africa (Eds). Proceedings of International Workshop, 19- 21 October 2009.Mekelle, Ethiopia, pp. 224

[14] Neumann, L., 1997 Opening speech. In: Proceedings of the International Workshop on "Opuntia in Ethiopia: State of Knowledge in Opuntia Research" February 23-27, 1997, Mekelle University, Ethiopia and Wiesbaden Polytechnic, Germany, pp 5-9

[15] Nobel, P.S. and E. Bobich, G., 2002. Environmental biology. pp 57-64. In: Nobel P.S. (ed.). CACTI Biology and uses. University of Berkley, LosAngeles, California.

[16] Nobel, P.S. 1988. Environmental biology of agaves and cacti. New York: Cambridge Univ. Press.

[17] Padulosi, S., 1998. Criteria for priority setting in initiatives dealing with underutilized crops in Europe. Paper presented at the European Symposium on Plant Genetic Resources for Food and Agriculture, Braunschweig, Germany, 29 June-5 July 1998.

[18] SAERT (Sustainable Agriculture and Environmental Rehabilitation in Tigray), 1994. Cactus fruit development project survey report. Mekelle, Ethiopia.

[19] Snyman. H.A., 2006. Root distribution with changes in distance and depth of two-year old cactus pears Opuntia ficus-indica and Opuntia robusta plants. South African Journal of Botany, Volume 72, pp. 434 441

[20] Stintzing F C and Carle R., 2005. Cactus stems (Opuntia species): a review on their chemistry, technology, and uses. Molecular Nutrition and Food Research, Volume 49, pp. 175-194

[21]Tesfay, B. Mulugeta, G. and Tadesse, A. 2011. Description of cactus pear (opuntia ficus-indica (1) mill.) cultivars from Tigray, northern Ethiopia. Research report No. 1. Tigray Agricultural Research Institute, Mekelle, Tigray, Ethiopia.

[22] Ting, L.P. 1985. Crassulacean acid metabolism. Ann. Rev. Plant Physiol., 36: 595-622.

[23] United States Department of Agriculture(USDA) 2012, Field Guide for Managing Prickly Pear in the Southwest. 12 PP.

[24] Velásquez, E. 1998. El nopal y su historia. Editorial Clío, Mexico 